\title{
Abnormal Secretion of Insulin and Glucagon by the In Vitro Perfused Pancreas of the Genetically Diabetic Chinese Hamster
}

\author{
Barbara J. Frankel, John E. Gerich, Ryoko Hagura, Rudy E. Fanska, \\ George C. Gerritsen, and Gerold M. Grodsky \\ From the Metabolic Research Unit and Departments of Medicine and Biochemistry and \\ Biophysics, University of California, San Francisco, California 94143 and the \\ Upiohn Company, Kalamazoo, Michigan 49001
}

A B S T R A C T Hereditary insulin-deficient diabetes mellitus occurs in certain sublines of nonobese Chinese hamsters. Several characteristics of this syndrome are similar to those seen in insulin-deficient human diabetics. Therefore, to characterize pancreatic islet function, dynamic insulin and glucagon release from normal and nonketotic diabetic hamster pancreases in response to glucose $(300 \mathrm{mg} / 100 \mathrm{ml})$ and theophylline $(10 \mathrm{mM})$, infused singly and together, was studied in vitro.

20 -min glucose infusions of normal hamster pancreases caused biphasic insulin release, consisting of a rapid first peak and a gradually rising second phase, similar to that reported for man in vivo. Both phases were significantly reduced in the diabetic pancreases. Theophylline alone stimulated similar nonphasic insulin release in both the normal and the diabetic pancreases. Glucose and theophylline together caused greater insulin release than either stimulant alone in both normals and diabetics; however, the diabetic response was still subnormal.

Glucose suppressed glucagon release from normal pancreases; suppression was significantly impaired in diabetics. Theophylline stimulated nonphasic glucagon release in both the normals and diabetics. Glucose partially suppressed the theophylline-stimulated release in both groups.

Insulin/glucagon molar ratios of the diabetics were consistently subnormal, although individual hormone levels often overlapped into the normal range.

This work was presented in part at the Western Section of the American Federation for Clinical Research, Carmel, Calif., 2 February 1973 (Clin. Res. 21: 273) and at the 33rd Annual Meeting of the American Diabetes Association, Chicago, I11., 24 June 1973 (Diabetes. 22(Suppl. 1) : 307.

Received for publication 22 June 1973 and in revised form 26 December 1973.
In summary, the pancreases of genetically diabetic Chinese hamsters perfused in vitro showed: (a) decreased first and second phase insulin release in response to glucose-containing stimuli-only partially ameliorated by theophylline-, and (b) impaired suppression of glucagon in response to glucose, resulting in (c) a decreased insulin/glucagon molar ratio. These data support the suggestion that both alpha and beta cells of diabetic pancreases may be insensitive to glucose.

\section{INTRODUCTION}

Overt diabetes mellitus in nonobese humans is generally characterized by a diminished insulin response to glucose (1). However, impaired insulin secretion may not be the only factor responsible for the abnormal glucose metabolism. Fasting hyperglucagonemia $(2,3)$, lack of suppression of plasma glucagon by glucose $(4,5)$, and excessive glucagon responses to amino acids $(2,6,7)$ have been reported to occur in diabetics. These observations suggest that abnormal pancreatic alpha-cell function may also be involved. The cause of these abnormalities and their interrelationship is unclear, since investigations have been hindered by clinical heterogeneity, uncertainties introduced by therapeutic intervention, and the lack of an appropriate animal model. In 1959, Yerganian and Meier (8) reported the occurrence of spontaneous diabetes among certain inbred sublines of Chinese hamsters. The syndrome is, at least in part, genetically determined, and its spectrum ranges in severity from intermittent glucosuria to ketoacidosis. Although prediabetic hamsters are hyperphagic (and may be mildly obese) when young $(9,10)$, the adults are the only spontaneously diabetic laboratory animals that are not obese $(11,12)$. They develop neuropathy 
(13), nephropathy (14), retinopathy (15), and abnormal lipid metabolism (16), closely resembling the complications of human diabetes. Moreover, the impaired insulin responses to glucose $(16-18)$, diminished pancreatic insulin content $(16,19,20)$, and abnormal islet morphology (21) reported in these animals parallel features found in lean human diabetics of both maturityonset and juvenile-onset types. Although no animal may be identical to the human, the diabetic Chinese hamster may be a particularly useful model for the nonobese insulin-deficient human diabetic.
There are few studies of in vitro pancreatic insulin secretion in the diabetic Chinese hamster $(17,18)$ and no reported data of in vitro glucagon secretion. Therefore, the present investigation was undertaken to study dynamic insulin and glucagon release from the isolated perfused pancreases of normal and nonketotic diabetic Chinese hamsters in response to glucose and theophylline (alone and in combination).

\section{METHODS}

Animals (Table I). Adult nonketotic diabetic Chinese hamsters (22) (Cricetulus griseus), 9-17 mo old, were

TABLE I

Characteristics of Normal and Diabetic Chinese Hamsters

\begin{tabular}{|c|c|c|c|c|c|c|c|c|c|c|}
\hline No. & Subline & $\begin{array}{l}\text { Genera- } \\
\text { tion }\end{array}$ & Sex & Age & $\begin{array}{c}\text { Body } \\
\text { weight }\end{array}$ & $\begin{array}{c}\text { Pancreas } \\
\text { weight }\end{array}$ & $\begin{array}{l}\text { Fasting } \\
\text { blood } \\
\text { glucose }\end{array}$ & $\begin{array}{c}\text { Pancreatic } \\
\text { insulin } \\
\text { content }\end{array}$ & $\begin{array}{c}\text { Duration } \\
\text { of } \\
\text { diabetes }\end{array}$ & $\begin{array}{c}\text { Mean } \\
\text { urine } \\
\text { (Testape } \\
0-4+\text { ) }\end{array}$ \\
\hline \multicolumn{11}{|l|}{ Normals } \\
\hline 1 & $\mathrm{CU}$ & 4 & $\mathrm{~F}$ & 16.8 & 24 & 190 & - & - & & \\
\hline 2 & AA & 5 & $\mathbf{M}$ & 13.6 & 28.9 & 150 & 81 & 0.616 & & \\
\hline 3 & $\mathrm{U}$ & 12 & $\mathrm{~F}$ & 13.9 & 23.5 & 287 & - & - & & \\
\hline 4 & $\mathrm{U}$ & 12 & $\mathrm{~F}$ & 13.5 & 23.5 & 230 & 145 & 0.652 & & \\
\hline 5 & $\mathrm{CU}$ & 5 & $\mathrm{~F}$ & 12.7 & 25.5 & 190 & 85 & 2.621 & & \\
\hline 6 & M & 6 & $\mathrm{~F}$ & 10.3 & 24.4 & 111 & 75 & 1.726 & & \\
\hline 7 & $\mathrm{U}$ & 14 & $\mathbf{M}$ & 10.4 & 27.7 & 184 & 108 & 1.008 & & \\
\hline 8 & $\mathbf{M}$ & 6 & $\mathrm{~F}$ & 14.3 & 22.4 & 203 & 80 & 0.711 & & \\
\hline 9 & $\mathrm{CU}$ & 6 & M & 12.0 & 33.4 & 246 & 98 & 1.060 & & \\
\hline 10 & $\mathbf{M}$ & 6 & M & 14.5 & 28.1 & 175 & 65 & 0.896 & & \\
\hline 11 & M & 7 & $\mathbf{M}$ & 14.6 & 28.5 & 186 & 111 & 0.197 & & \\
\hline$\overline{\mathrm{X}}$ & & 8 & & 13.3 & 26.4 & 196 & 94 & 1.054 & & \\
\hline SE & & 1 & & 0.6 & 1.0 & 14 & 8 & 0.240 & & \\
\hline \multicolumn{11}{|c|}{ Diabetics } \\
\hline 1 & $\mathrm{AC}$ & 3 & $\mathbf{M}$ & 13.5 & 29 & 215 & - & - & 11.2 & 2 \\
\hline 2 & $\mathrm{~L}$ & 17 & $\mathbf{M}$ & 9.3 & 28 & 182 & - & - & 5.8 & 3 \\
\hline 3 & $\bar{Z}$ & 6 & $\mathbf{M}$ & 11.9 & 27 & 191 & - & - & 9.9 & 3 \\
\hline 4 & L & 17 & $\mathrm{~F}$ & 12.4 & 24 & 201 & - & - & 10.2 & 3 \\
\hline 5 & $\mathrm{X}$ & 6 & $\mathrm{~F}$ & 16.9 & 23 & 176 & - & - & 15.2 & 4 \\
\hline 6 & $\mathrm{~L}$ & 17 & $\mathbf{M}$ & 9.7 & 25 & 200 & - & - & 6.7 & 3 \\
\hline 7 & $\bar{X}$ & 6 & $\mathrm{~F}$ & 11.8 & 25.1 & 170 & 500 & 0.297 & 9.5 & 4 \\
\hline 8 & $F$ & 6 & M & 10.7 & 31.4 & 150 & 560 & 0.333 & 8.6 & 2 \\
\hline 9 & $\mathrm{X}$ & 7 & $\mathbf{M}$ & 14.7 & 32.0 & 140 & 210 & 0.205 & 13.5 & 4 \\
\hline 10 & $\mathrm{XA}$ & 8 & $\mathrm{~F}$ & 14.2 & 26.5 & 170 & 240 & 0.308 & 12.6 & 4 \\
\hline 11 & $Z$ & 7 & $\mathbf{M}$ & 14.0 & 26.0 & 167 & 200 & 0.797 & 12.1 & 4 \\
\hline 12 & AC & 4 & $\mathrm{~F}$ & 13.6 & 25.9 & 190 & 460 & 0.681 & 12.0 & 4 \\
\hline 13 & $\mathrm{X}$ & 8 & M & 11.0 & 25.6 & 150 & 260 & 0.208 & 8.9 & 4 \\
\hline 14 & $A B$ & 6 & $\mathrm{~F}$ & 12.6 & 26.0 & 241 & 305 & 0.402 & 11.2 & 2 \\
\hline 15 & $\mathrm{~F}$ & 7 & $\mathbf{M}$ & 12.8 & 33.3 & 205 & 340 & 0.528 & 10.8 & 4 \\
\hline 16 & $\mathrm{XA}$ & 8 & M & 14.6 & 34.5 & 188 & 245 & 0.325 & 13.1 & 3 \\
\hline 17 & $\mathrm{AB}$ & 6 & $\mathbf{M}$ & 16.0 & 37.8 & 228 & 260 & 0.023 & 14.7 & 4 \\
\hline $\mathbf{X}$ & & 8 & & 12.9 & 28.2 & 186 & 326 & 0.373 & 10.9 & 3 \\
\hline $\mathrm{SE}$ & & 1 & & 0.5 & 1.0 & 7 & 38 & 0.067 & 0.6 & 0 \\
\hline${ }^{*} P<$ & & & & NS & NS & NS & 0.0001 & 0.01 & & \\
\hline
\end{tabular}

* Versus normals, two-sided Student $t$. 
TABLE II

Insulin and Glucagon Secretion from Normal and Diabetic Hamster Pancreases

\begin{tabular}{|c|c|c|c|c|c|c|}
\hline \multirow[b]{2}{*}{ No. } & \multicolumn{3}{|c|}{ Insulin* } & \multicolumn{3}{|c|}{ Glucagon* } \\
\hline & Glucose & Theophylline & $\begin{array}{l}\text { Glucose plus } \\
\text { theophylline }\end{array}$ & Glucose & Theophylline & $\begin{array}{l}\text { Glucose plus } \\
\text { theophylline }\end{array}$ \\
\hline Normals & \multicolumn{3}{|c|}{$n g / 20 \min$} & \multicolumn{3}{|c|}{$n g / 20 \min$} \\
\hline 1 & 219.1 & - & - & - & - & - \\
\hline 2 & 101.4 & 0.0 & 409.7 & - & - & - \\
\hline 3 & 310.4 & 18.6 & 503.0 & - & - & - \\
\hline 4 & 54.9 & 0.1 & 230.4 & - & - & - \\
\hline 5 & 33.2 & 33.3 & 296.5 & - & - & - \\
\hline 6 & 145.1 & 7.5 & 322.8 & 2.22 & 12.84 & 7.24 \\
\hline 7 & $261: 8$ & 60.5 & 397.7 & 0.90 & 2.84 & 9.68 \\
\hline 8 & 213.1 & 11.9 & 296.7 & 4.67 & 18.03 & 0.00 \\
\hline 9 & 257.0 & 41.3 & 315.6 & 5.10 & 5.75 & 6.53 \\
\hline 10 & 225.2 & 12.0 & 321.3 & 2.16 & 16.31 & 2.57 \\
\hline 11 & 126.2 & 218.9 & 506.9 & 5.43 & 16.55 & 9.38 \\
\hline$\overline{\mathbf{X}}$ & 177.0 & 40.4 & 360.1 & 3.41 & 12.05 & 5.90 \\
\hline $\mathrm{SE}$ & 27.3 & 20.8 & 29.0 & 0.77 & 2.58 & 1.58 \\
\hline \multicolumn{7}{|l|}{ Diabetics } \\
\hline 1 & 233.6 & - & - & - & - & - \\
\hline 2 & 44.0 & - & - & - & - & - \\
\hline 3 & 316.5 & - & - & - & - & - \\
\hline 4 & 86.4 & - & - & - & - & - \\
\hline 5 & 12.5 & - & - & - & - & - \\
\hline 6 & 197.6 & - & - & - & - & - \\
\hline 7 & 9.7 & - & - & 一 & - & - \\
\hline 8 & 12.5 & - & - & - & - & - \\
\hline 9 & 15.8 & 0.9 & 4.4 & - & - & - \\
\hline 10 & 5.2 & 13.3 & 65.3 & - & - & - \\
\hline 11 & 31.9 & 100.6 & 378.0 & - & - & - \\
\hline 12 & 7.1 & 8.9 & 0.5 & - & - & - \\
\hline 13 & 50.4 & 16.4 & 66.9 & 7.85 & 13.91 & 5.37 \\
\hline 14 & 139.0 & 68.0 & 364.6 & 13.71 & 43.34 & 12.26 \\
\hline 15 & 52.3 & 13.5 & 225.7 & 5.46 & 6.92 & 6.47 \\
\hline 16 & 107.9 & 135.9 & 139.2 & 13.47 & 18.77 & 33.70 \\
\hline 17 & 208.7 & 173.0 & 388.5 & 5.06 & 49.09 & 21.68 \\
\hline$\overline{\mathbf{X}}$ & 90.1 & 58.9 & 181.5 & 9.11 & 26.41 & 15.90 \\
\hline $\mathrm{SE}$ & 23.2 & 21.3 & 54.0 & 1.89 & 8.35 & 5.31 \\
\hline$\ddagger P<$ & 0.05 & NS & 0.01 & 0.02 & NS & $\operatorname{NS}(0.1)$ \\
\hline
\end{tabular}

* Calculated from area under the curve.

‡ Versus normals, two-sided Student $t$.

studied. All had fasting hyperglycemia and glucosuria but no ketonuria since onset of diabetes at age 6-14 wk. The untreated diabetics came from seven sublines that had been brother-sister inbred for 3-17 generations. Once categorized at 5 mo of age, these animals rarely progress to a more severe or less severe form of diabetes. ${ }^{1}$ Nondiabetic hamsters from four normal inbred sublines of the same colony that had exhibited no glucosuria for at least five generations served as controls. There was no difference between normals and diabetics in mean age, body weight, or pan-

\footnotetext{
${ }^{1}$ Gerritsen, G. C., and W. E. Dulin. Personal communication.
}

creas weight. Food was withheld about $18 \mathrm{~h}$ before sacrifice. All diabetics were markedly hyperglycemic at laparotomy $(326 \pm 38 \mathrm{mg} / 100 \mathrm{ml})$ when compared with the normals $(94 \pm 8 \mathrm{mg} / 100 \mathrm{ml}), P<0.0001$.

Perfusion system. The dissection procedure and apparatus were adapted from the system of Grodsky, Bennett, Smith, and Schmid (23) and Grodsky and Fanska (24) with the following aiterations: the surgical procedure, apparatus, and tubing were adjusted to kandle 0.2-g hamster pancreases instead of $1.2-\mathrm{g}$ rat pancreases. A constant $1.5-\mathrm{ml} / \mathrm{min}$ flow of unrecycled perfusate was pumped through the pancreases by a multispeed peristaltic finger pump (Harvard Apparatus Co., Inc., Millis, Mass.). Peris- 


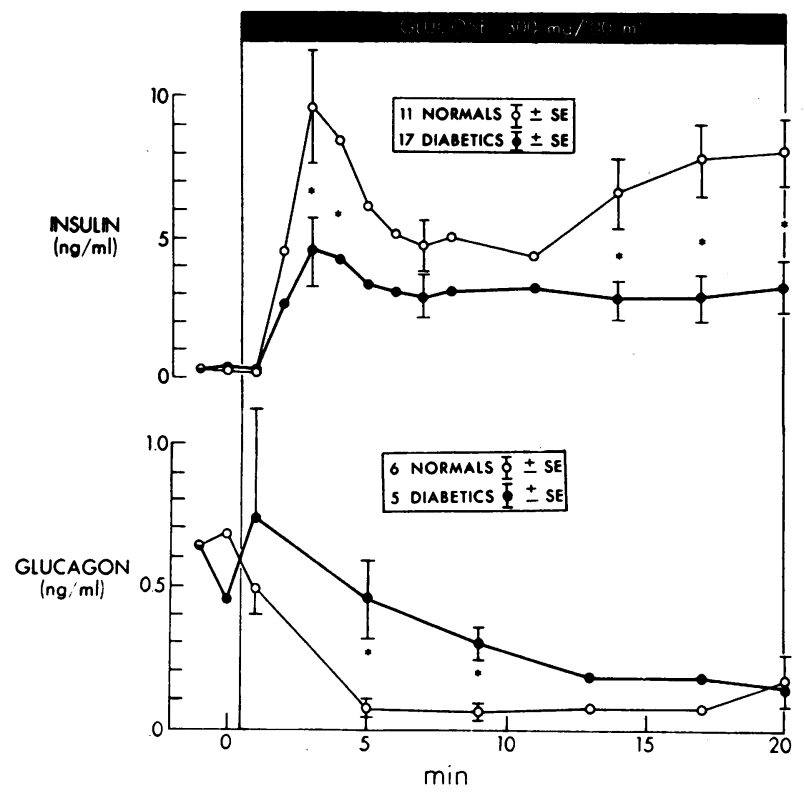

Figure 1 Mean ( $\pm \mathrm{SE})$ insulin and glucagon responses of normal (O) and diabetic ( $\bullet$ Chinese hamster pancreases to glucose infusion $(300 \mathrm{mg} / 100 \mathrm{ml})$. Insulin measurements from normals (nos. 1-11) and diabetics (nos. 1-17); glucagon measurements from normals (nos. 6-11) and diabetics (nos. 13-17), as designated in Table I. (*) $P<0.05$.

talsis from this pump $(0.5-1.0 \mathrm{~mm} \mathrm{Hg})$ is negligible. Arterial/venous oxygen tension was measured during several perfusions, and oxygen uptake was calculated; uptake $(0.06 \mathrm{ml} \mathrm{O} / \mathrm{g}$ dry $\mathrm{wt} / \mathrm{min})$ was constant and similar to that of the perfused rat pancreas (25). Oxygen uptake, gastric juice secretion, and duodenal peristalsis remained constant throughout the perfusions. Concentrated glucose was added via sidearm syringe in buffer at a rate of 0.1 $\mathrm{ml}$ buffer $/ \mathrm{min}$. Since anhydrous theophylline was not readily soluble in small amounts of perfusate, a parallel pumping system was used to supply perfusate containing $10 \mathrm{mM}$ theophylline dissolved in buffer. The portal vein effluent, collected in an ice bath at 1-min intervals by automatic fraction collector, was stored until assay (within 4 wk) at $-20^{\circ} \mathrm{C}$. After the perfusion, the pancreas was dissected free from the duodenum and other tissues, weighed, and frozen until extraction.

Experimental design. After approximately $15 \mathrm{~min}$ equilibration and collection of two zero-time samples (min - 1 and 0 ), the pancreases from a total of 11 normal and 17 diabetic hamsters were exposed to a 20 -min glucose infusion $(300 \mathrm{mg} / 100 \mathrm{ml} ; 16.7 \mathrm{mM})$. To obtain more information with the limited number of animals available, some of the pancreases were subsequently perfused with additional stimuli during which insulin (10 normals, 9 diabetics) and glucagon ${ }^{2}$ ( 6 normals, 5 diabetics) responses were measured (Table II). 10-min rest periods, found adequate in similar perfusions of rat pancreases, were interposed between stimuli to minimize the effects one stimulation might have on the next. In these experiments, pan-

${ }^{2}$ Assay of glucagon became available after normals (nos. 1-5) and diabetics (nos. 1-12) had already been studied. creases were exposed to the following agents: (a) glucose, $300 \mathrm{mg} / 100 \mathrm{ml}(16.7 \mathrm{mM}), 20 \mathrm{~min}$, followed by $(b)$ theophylline, $10 \mathrm{mM}(180 \mathrm{mg} / 100 \mathrm{ml}), 20 \mathrm{~min}$, and $(c)$ glucose plus theophylline (same concentrations as above), $20 \mathrm{~min}$.

Insulin assay. Serial dilutions of pancreatic extracts from Chinese hamsters were compared with rat, beef, and pork insulin standards by using a solid phase modification of a single antibody radioimmunoassay (26), incorporating the Automated Pipetting Station (Micromedic Systems, Inc., Philadelphia, Pa.). Proportional cross-reaction was. obtained with pork or beef but not rat insulin standards. Since pork insulin was slightly better than beef for the concentration ranges involved, all samples of perfusate were assayed against pork insulin standards.

Glucagon assay. Serial dilutions of pooled pancreatic extracts from Chinese hamsters gave proportional results when compared with beef-pork standards. Therefore, glucagon was measured against beef-pork glucagon standards by using a radioimmunoassay system (27) similar to that employed for the perfused rat pancreas (28). The Unger antiserum, $30 \mathrm{~K}$, which is highly specific for pancreatic glucagon (29), was employed. In brief, duplicate samples $(0.2 \mathrm{ml})$ of perfusate collected on ice in tubes containing $15 \%$ EDTA $(0.02 \mathrm{ml})$ were added to $0.6 \mathrm{ml}$ glycine buffer, $\mathrm{pH} 8.8$, containing approximately $16 \mathrm{pg}$ of $\left[{ }^{125} \mathrm{I}\right]$ glucagon (Cambridge Nuclear Corp., Cambridge, Mass.). To this mixture, $0.4 \mathrm{ml}$ antiserum (final dilution 1:40,000) was added. After incubation at $4^{\circ} \mathrm{C}$ for 4 days, bound and free glucagon were separated by dextran-coated charcoal. The minimal sensitivity of this assay was $0.025 \mathrm{ng} / \mathrm{ml}$. Between 0.1 and $0.2 \mathrm{ng} / \mathrm{ml}$, the interassay coefficient of variation was $15 \%$ and the intrassay coefficient was $10 \%$. The glucagon secretion rates per gram of pancreas reported here are comparable to those from normal perfused rat pancreases in this laboratory (28).

To evaluate the possible degradation of glucagon in our pancreatic system, $\left[{ }^{125} \mathrm{I}\right]$ glucagon was perfused for $60 \mathrm{~min}$ through both a normal and diabetic preparation. At various critical times, arterial and venous samples were collected in an ice bath, frozen at $-20^{\circ} \mathrm{C}$ for $24 \mathrm{~h}$, allowed to stand from $\frac{1}{2}$ to $4 \mathrm{~h}$ at $4^{\circ} \mathrm{C}$, and then subjected to hydrodynamic flow chromatography with a $0.05 \mathrm{M}$ barbital buffer (26). Similar and minor degradation (mean $<10 \%$ ) was observed at all times ( $\min -10,-5,0,5,15,25,35$, and 45) throughout these typical experiments.

Pancreatic insulin content. Whole frozen pancreases obtained after perfusion were thawed, homogenized in cold trichloroacetic acid, and extracted for insulin by using a modification of an acid-alcohol, alkalinization, and etheralcohol technique (30). Recovery of added [ ${ }^{131} \mathrm{I}$ ] porcine insulin was about $80 \%$.

Blood glucose measurement. Blood glucose was determined by a glucose oxidase technique with the Ames Reflectance Meter (Ames Co., Div. Miles Lab., Inc., Elkhart, Ind.) on heparinized samples obtained from the vena cava or abdominal aorta during laparotomy.

Statistics. Linear regression and two-sided paired analysis or Student's $t$ tests were used to analyze data.

\section{RESULTS}

Insulin and glucagon responses to glucose (300 $\mathrm{mg} / 100 \mathrm{ml}$ ) (Fig. 1 and Table II)

Insulin. Basal (unstimulated) secretion was similar in all animals. The normal hamster pancreases responded 
to continuous glucose infusion in a biphasic manner: the first phase consisted of a spikelike release that reached maximal levels within $4 \mathrm{~min}$; this was followed by a nadir and the second phase, a more prolonged response. The first peak, or phase, was taken as the area under the curve during the first $7 \mathrm{~min}$ of stimulation, and the second phase as the area thereafter. Despite a wide overlap of normal and diabetic responses, the mean ( $\pm \mathrm{SE}$ ) diabetic first and second phases of insulin release were significantly reduced to a similar extent ( $54 \pm 15 \%$ and $50 \pm 13 \%$ of normal, respectively). In both individual normal and diabetic animals, the amount of insulin released in the first phase was positively correlated to second phase release $(r=0.79, P<0.005$; $r=0.94, P<0.0005$, respectively).

Other studies from this laboratory indicate that both phases begin simultaneously and overlap during the first few minutes of stimulation (31). In many cases, simply separating the phases at the nadir overestimates the first phase. Theoretically, it is more accurate to extrapolate the second phase to zero and subtract the overlap from the first phase (32); however, extrapolation is often difficult and arbitrary. With this approach, applied to the mean data in Fig. 1, inhibition of first and second phases was 53 and $49 \%$ of normal, respectively.

Mean pancreatic insulin content after perfusion of the diabetic pancreases $(0.373 \pm 0.067 \mathrm{U} / \mathrm{g})$ was significantly less than that in the normals $(1.054 \pm 0.240 \mathrm{U} / \mathrm{g}, P<$ 0.01) (Table I). However, when individual animals were compared, pancreatic insulin content, number of inbred generations, age, body weight, fasting blood glu-

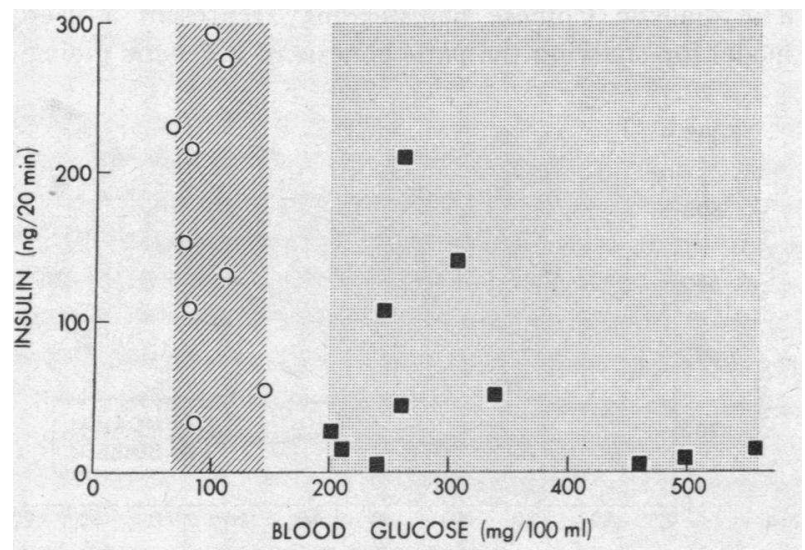

FIGURE 2 Relation between in vitro insulin responses and the degree of hyperglycemia of individual normal $(O)$ and diabetic ( $\boldsymbol{\square})$ Chinese hamsters. Insulin secretion refers to total release during a 20 -min glucose infusion $(300 \mathrm{mg} / 100$ $\mathrm{ml})$ from the individual pancreases summarized in Fig. 1. Glucose values were from blood collected from animals during laparotomy immediately before pancreatic removal (Table I). Glucose determinations were performed in 9 of 11 normal and 11 of the 17 diabetic animals.

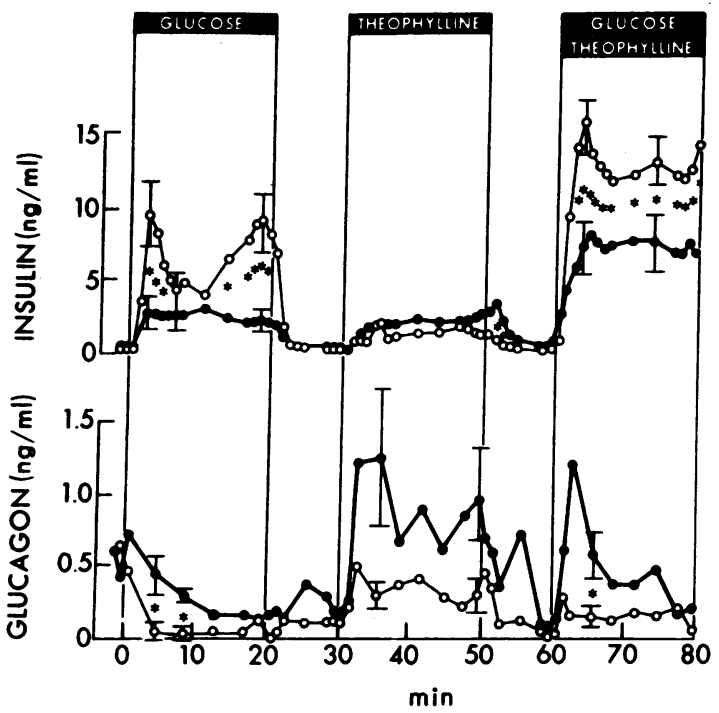

Figure 3 Mean ( $\pm \mathrm{SE}$ ) insulin and glucagon responses of normal $(O)$ and diabetic (๑) Chinese hamster pancreases to 20 -min infusions of glucose $(300 \mathrm{mg} / 100 \mathrm{ml})$, theophylline $(10 \mathrm{mM})$, and glucose $(300 \mathrm{mg} / 100 \mathrm{ml})$ plus theophylline $(10 \mathrm{mM})$. Insulin measurements from 10 normals (nos. 2-11) and 9 diabetics (nos. 9-17); glucagon measurements from 6 normals (nos. 6-11) and 5 diabetics (nos. 13-17). (*) $P<0.05$.

cose at laparotomy, (Fig. 2), and duration of diabetes did not correlate with the amount of insulin released in response to glucose in either normals or diabetics. Imparred insulin release in the diabetics was correlated with mean urine sugar, measured every 2 wk during life $(r=0.441, P<0.05)$.

Glucagon. Basal secretion was similar in both normal and diabetic groups. Glucose suppressed glucagon secretion in normals within $5 \mathrm{~min}$; there was maximum suppression to a mean of less than $10 \%$ of zero-time by 10 min. In the diabetics, glucagon release was suppressed to only $56 \%$ during the same period. Total glucagon secretion during this interval (Table II) was significantly greater $(P<0.02)$ in the diabetics than in the normals. After the glucose infusion, both normal and diabetic glucagon levels did not return to the preglucose values, but established a new lower basal level (Fig. 3).

\section{Insulin and glucagon responses to theophylline}

\section{$(10 \mathrm{mM})$ (Fig. 3 and Table II)}

Insulin. Theophylline caused similar, small but significant, nonphasic release from both normal and diabetic pancreases.

Glucagon. Theophylline caused nonphasic glucagon release in both groups. Although the mean glucagon response of the diabetic pancreases exceeded that of the normals, this difference was not significant. In additional experiments, theophylline, introduced as the initial stim- 


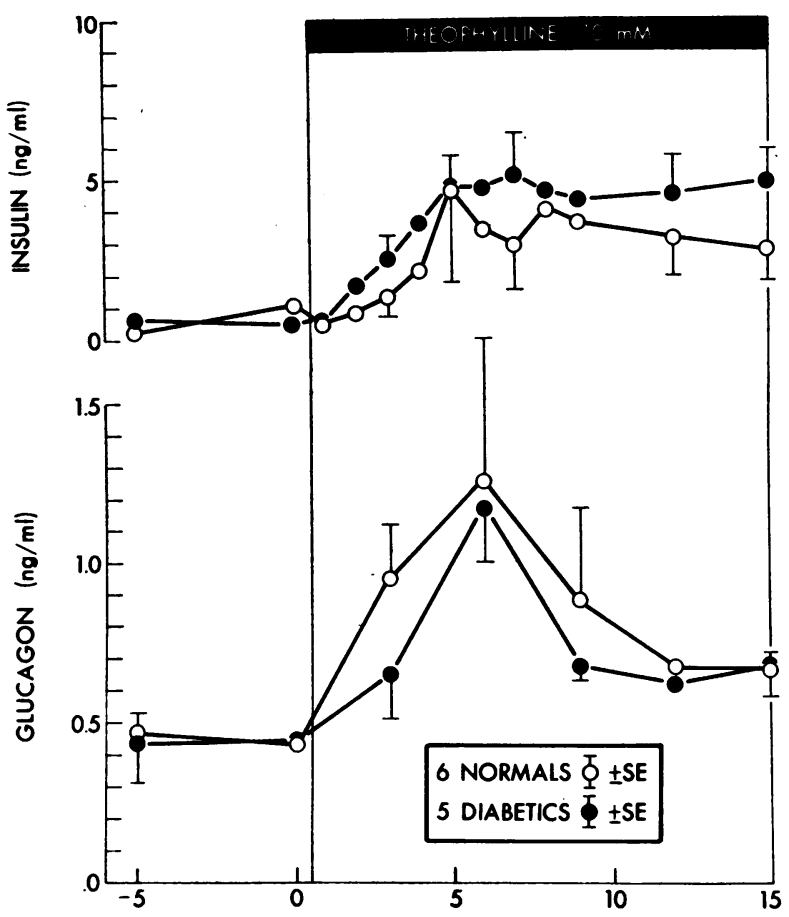

Figure 4 Mean ( \pm SE) insulin and glucagon responses of normal (O) and diabetic (๑) Chinese hamster pancreases stimulated by theophylline alone $(10 \mathrm{mM})$ without any prior stimulus. The pancreases were obtained from similar animals and were involved in other studies to be reported in detail elsewhere.

ulus, caused similar glucagon release from six diabetic and five normal pancreases (Fig. 4).

Insulin and glucagon responses to glucose ( 300 $\mathrm{mg} / 100 \mathrm{ml}$ ) plus theophylline $(10 \mathrm{mM}$ ) (Fig. 3 and Table II)

Insulin. The insulin response of the normals was biphasic and significantly greater than during either glucose or theophylline alone. The response of the diabetics to this combined stimulation was also greater than to either stimulant alone, total insulin release being quantitatively similar to that in the normals stimulated by glucose alone. However, the diabetics' response was still significantly less $(P<0.01)$ than the normals' response to this same combined stimulation.

Glucagon. In the normals and diabetics, glucose plus theophylline tended to cause less glucagon release than did theophylline alone. The diabetics' glucagon responses to glucose plus theophylline were greater than the normals'; however, the statistical significance of this difference $(P=0.08)$ was not as definitive as when the pancreases were exposed to glucose alone $(P=0.02)$.
Comparison of total insulin and glucagon release and insulin/glucagon molar ratios

Total insulin and glucagon released (area under the curve for $0-80 \mathrm{~min}$ ) from the individual pancreases are summarized in Fig. 5. Two diabetics had total insulin responses within the range observed for the normal animals but had excessive glucagon release; two diabetics had glucagon responses within the range of the normals but had lower insulin levels; no diabetic had both normal insulin and normal glucagon responses. This resulted in the diabetics consistently having decreased insulin/glucagon molar ratios for the total 80 -min interval (Fig. 6). There was no evidence that those diabetics with the highest insulin release had the lowest glucagon release. Rather, those diabetics with the highest insulin release also had the highest glucagon release (Fig. 5).

\section{Influence of subline on insulin release}

A total of four normal and seven diabetic Chinese hamster sublines were "sampled"' during these experiments (Table I). Although too few animals were studied to give a large $n$ in each subline, several sublines showed large variations in hormone release from one animal to the next, while one particular subline, $\mathrm{X}$, consistently showed poorer insulin release in response to glucose. There was no correlation in the diabetics between the mean insulin response of the subline and the number of generations that subline had been inbred, blood glucose at laparotomy, or mean biweekly urine sugar.

\section{DISCUSSION}

The diabetic Chinese hamster may represent a useful model for studying the pathogenesis of a genetic diabetic

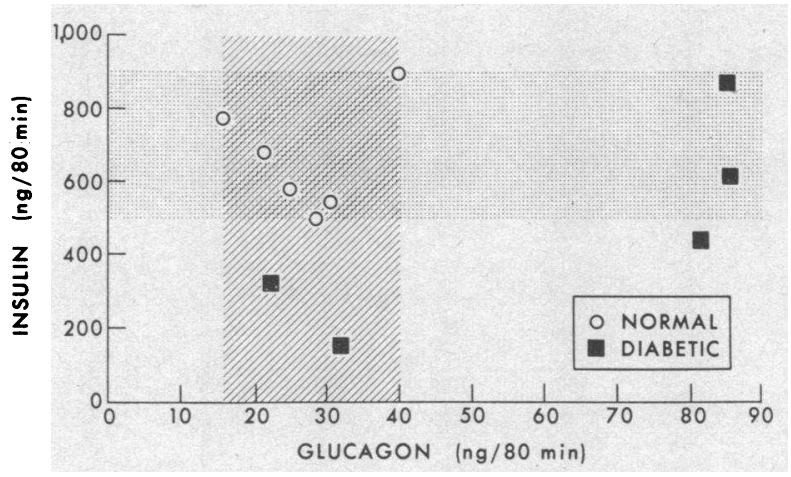

FIgURe 5 Comparison of individual total insulin and glucagon release (as area under the curve) during the 80 -min experimental period (Fig. 3) from normal (O) and diabetic (ם) Chinese hamster pancreases. Shaded areas are for visual convenience. Horizontal area shows the range of insulin responses observed among the normal pancreases; vertical area shows the range of glucagon responses observed among normal pancreas. 
syndrome similar to that occurring in nonobese insulindeficient humans. The present investigation had the following objectives: $(a)$ to ascertain whether dynamic insulin responses to glucose in vitro were abnormal and whether there was a preferential defect in early or late insulin release; $(b)$ to determine whether abnormal glucagon secretion also occurred in this diabetic animal, since abnormalities in pancreatic glucagon secretion have been shown to occur in human diabetes $(3-7,33)$; and $(c)$ to determine the effects of theophylline on insulin and glucagon secretion, since similar agents have been reported to ameliorate impaired insulin release in human diabetics (34).

Malaisse, Malaisse-Lagae, Gerritsen, Dulin, and Wright (17) and Chang (18) have reported impaired insulin release from isolated pancreatic tissue and islets from diabetic Chinese hamsters. Their studies, however, did not permit clear evaluation of the individual phases of insulin release. Simpson, Benedetti, Grodsky, Karam, and Forsham (35) suggested that early insulin release may be preferentially diminished in human diabetics, but they did not study second phase release. Cerasi and Luft (36) recently found that both phases of insulin release are significantly impaired in human diabetics and suggested that the mechanisms governing both phases of insulin responses to glucose are similar. Evidence for a common glucose signal for both phases is derived from the observation that in normal rats (31) and man (36) the glucose $K_{m}$ for the first and second phases are the same. Both phases of insulin release were impaired with equal frequency and to a similar extent in our diabetic hamsters. These findings are thus consistent with the concept of an early defect of glucose action, possibly involving a glucose receptor $(36,37)$ rather than a preferential defect in some mechanism underlying one of the phases. This defect appears relatively specific for glucose, since theophylline both stimulated insulin release and augmented glucose-stimulated insulin release similarly in both normals and diabetics. Although total pancreatic insulin was less in the diabetics, this did not appear to be a major cause of their decreased glucosestimulated insulin release, since response to theophylline was normal and since there was no correlation between insulin release and stored insulin within either the normal or diabetic groups. Our findings are also in accord with those in man by Robertson and Porte (37), who found that, despite abnormal insulin responses to glucose, diabetics' insulin responses to isoproterenol were normal, suggesting a defect specific for glucosemediated insulin secretion.

Elevated fasting glucagon levels have been reported in human diabetics with $(3,6,33)$ and without (38) concomitant hyperglycemia. From the diabetic hamster pancreases, basal glucagon secretion (at zero glucose) was similar to normals. These "basal" data probably are

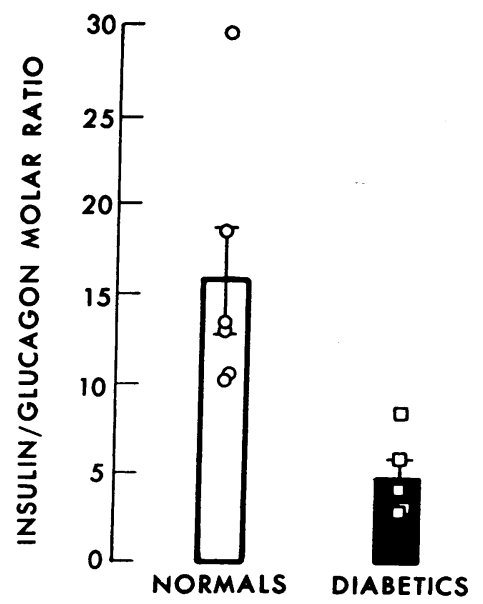

FIGURE 6 Individual and mean $( \pm \mathrm{SE})$ molar ratios of total secreted insulin and glucagon from normal $(O)$ and diabetic ( $\square)$ Chinese hamster pancreas, $P<0.005$. Data taken from Fig. 5.

not directly comparable to fasting hormone levels in man where glucose concentrations are not zero. Furthermore, since initial glucagon levels were higher than during any of the subsequent zero glucose rest periods, it is possible that surgery and the absence of glucose during the equilibration periods may have acted as a combined stress and hypoglycemic stimulus, permitting the normal pancreases to increase secretion up to the diabetic levels. This high early glucagon release was not due to artifacts caused by pancreatic degradative processes, since the integrity of added $\left[{ }^{125} \mathrm{I}\right]$ glucagon remained constant at all times during a typical perfusion.

Müller, Faloona, and Unger (39) reported that hyperglycemia in normal dogs made diabetic by alloxan failed to suppress glucagon secretion normally unless exogenous insulin was given. Human diabetics, however, show poor glucagon suppression by glucose even when supplemented with abundant exogenous insulin (5). In the present experiments, glucose did not suppress glucagon secretion as readily in the genetic diabetics as in the normal hamsters, even though some of the diabetic animals had normal insulin responses to glucose and to theophylline. Furthermore, glucagon suppression did not correlate with pancreatic insulin content. Although glucagon responses to theophylline were substantially suppressed by glucose in the normal hamsters, suppression was not as great in the diabetics. These results suggest that the cause for the lack of glucagon suppression in the spontaneously diabetic Chinese hamster and the alloxandiabetic dog may be different, and that the abnormal glucagon secretion from the hamster pancreas is not secondary to a lack of insulin per se. As has been suggested for human diabetes (5), it is possible that there may be a primary defect of glucose recognition in dia- 
betic Chinese hamster pancreatic alpha cells. However, one still cannot exclude the possibility that this defect of the alpha cell was caused by acute or chronic insulin deficiency. It would thus be instructive to see if any abnormalities of glucagon secretion remained after in vitro addition of insulin or after prolonged control of the blood glucose with insulin in vivo.

The present studies demonstrate that theophylline not only increases insulin secretion but is also a stimulator of glucagon release, consistent with the observations of Jarrousse, Rançon, Rosselin, and Freychet (40) using the newborn rat pancreas. Thus, both the pancreatic alpha and beta cell may be positively modulated by increased cyclic AMP - a conclusion also recently suggested for man (41).

The similar responses to theophylline in normal and diabetic pancreases suggest that the mechanism through which theophylline acts (presumably through elevating intracellular cyclic AMP) is relatively intact in both the beta and alpha cell of the genetically diabetic hamster. Our results are similar to Cerasi and Luft's finding (34) that aminophylline could partially "normalize" some human prediabetics' insulin responses to glucose. Our experiments, however, showed that theophylline augmented, but did not quantitatively normalize, the glucose-stimulated insulin release in the diabetics.

Certain diabetic pancreases had total insulin release within the range of the normals but excessive glucagon secretion; others had subnormal insulin release with normal glucagon secretion. None had responses in the range of the normals of both hormones. This relationship could be expressed as a significantly $(P<0.02)$ decreased insulin/glucagon ratio. Thus, in agreement with Unger (42), the insulin/glucagon molar ratio, although not a significant number in itself, since it suggests an unproven linear relationship, may nevertheless represent the status of pancreatic responses more accurately than measurement of the level of either hormone alone. Moreover, the insulin/glucagon molar ratio may have clinical applicability by demonstrating in a single individual an inappropriate level of insulin for a given glucagon level and vice versa.

Diabetes is often attributed to genetics when identical twins both develop the disease and to environment when they do not. There are several sublines of Chinese hamsters which have been brother-sister inbred for 10 or more generations and thus have, theoretically, more than $90 \%$ genetic homozygosity (43). Nevertheless, these animals are not $90 \%$ phenotypically identical with regard to severity of their diabetes, suggesting a contribution by environmental factors. Despite our careful selection for nonketotic diabetics of similar severity, there was a wide overlap of the individual normal and diabetic insulin responses to glucose. This variation in insulin release was noted both between and within sublines, suggesting what is often suspected of human diabetes mellitus-that we may be dealing with several different genetic contributions to the diabetic disease. The fact that one subline with consistently low insulin (X) was no more diabeic than the others supports the probability that impaired beta-cell function is not solely responsible for genetic diabetes. The recent series represents the first attempt to examine hormone secretion from different sublines, but more animals must be studied in each diabetic hamster subline before definite conclusions can be drawn.

In conclusion, the diabetic Chinese hamster may be a valuable experimental model for studying the metabolic abnormalities of a genetic diabetic syndrome not easily measured in man in vivo. In the diabetic hamster, both phases of insulin release in response to glucose were reduced; insulin and glucagon responses to theophylline were normal; theophylline enhanced but did not completely normalize glucose-stimulated insulin release; inhibition of glucagon secretion by glucose was impaired and did not appear to be correlated with insulin deficiency; and insulin/glucagon molar ratios were reduced despite occasional normal levels of one or the other hormone. These results suggest that both alpha and beta cells of the diabetic pancreas may have a relatively specific impaired sensitivity to glucose.

\section{ACKNOWLEDGMENTS}

We wish to thank the Upjohn Company (Drs. George C. Gerritsen and William E. Dulin), Kalamazoo, Mich., for generously supplying the hamsters, and Drs. M. Mozen and A. Pappenhagen of Cutter Laboratories, Berkeley, Calif., and James B. Lesh of the Armour Pharmaceutical Company, Kankakee, Ill., for their generous assistance in providing the large supplies of albumin necessary for these studies.

We also wish to thank Miss Florence Schmid, Miss Betty Lewis, Mrs. Mary Ann Jones, Miss Michele Manning, and Mr. Paul Indman for their excellent technical assistance.

This work was supported in part by Grant AM-01401 from the National Institutes of Arthritis and Metabolic Diseases, U. S. Public Health Service, a grant from the Kroc Foundation, Santa Ynez, Calif., a grant from the Hoechst Pharmaceutical Company, Somerville, N. J., a grant from the Upjohn Company, Kalamazoo, Mich., and a grant from the Levi J. and Mary Skaggs Foundation, Oakland, Calif.

\section{REFERENCES}

1. Kipnis, D. M. 1968. Insulin secretion in diabetes mellitus. Ann. Intern. Med. 69: 891.

2. Unger, R. H., E. Aguilar-Parada, W. A. Müller, and A. M. Eisentraut. 1970. Studies of pancreatic alpha cell function in normal and diabetic subjects. J. Clin. Invest. $49: 837$.

3. Heding, L. G., and S. M. Rasmussen. 1972. Determination of pancreatic and gut glucagon-like immunore- 
activity (GLI) in normal and diabetic subjects. Diabetologia. 8 : 408 .

4. Müller, W. A., G. R. Faloona, E. Aguilar-Parada, and R. H. Unger. 1970. Abnormal alpha-cell function in diabetes. Response to carbohydrate and protein ingestion. N. Engl. J. Med. 283: 109.

5. Unger, R. H., L. L. Madison, and W. A. Müller. 1972. Abnormal alpha-cell function in diabetics. Response in insulin. Diabetes. 21 : 301.

6. Wise, J. K., R. Hendler, and P. Felig. 1973. Evaluation of alpha-cell function by infusion of alanine in normal, diabetic, and obese subjects. N. Engl. J. Med. 288: 487.

7. Gerich, J. E., M. Langlois, C. Noacco, J. H. Karam, and P. H. Forsham. 1973. Lack of glucagon response to hypoglycemia in diabetes: evidence for an intrinsic alpha cell defect. Science (Wash. D. C.). 182: 171.

8. Yerganian, G., and H. Meier. 1959. Spontaneous hereditary diabetes mellitus in the Chinese hamster (Cricetulus griseus). Fed. Proc. 18: 514.

9. Gerritsen, G. C., and M. C. Blanks. 1970. Preliminary studies on food and water consumption of prediabetic Chinese hamsters. Diabetologia. 6: 177.

10. Gerritsen, G. C., and W. E. Dulin. 1972. Effect of diet restriction on onset of development of diabetes in prediabetic Chinese hamsters. Acta Diabetol. Lat. 9 (Suppl. 1) : 597 .

11. Dulin, W. E., A. Y. Chang, and G. C. Gerritsen. 1971. Comparison of diabetes in the Chinese hamster, $\mathrm{KK}$ mouse and $\mathrm{db}$ mouse. In Diabetes. R. R. Rodriguez and J. Vallance-Owen, editors. Excerpta Medica Foundation, Publishers, Amsterdam. 868.

12. Renold, A. E., and I. Burr. 1970. The pathogenesis of diabetes mellitus. Possible usefulness of spontaneous hyperglycemic syndromes in animals. Calif. Med. 112: 23.

13. Luse, S. A., G. C. Gerritsen, and W. E. Dulin. 1970. Cerebral abnormalities in diabetes mellitus: an ultrastructural study of the brain in early onset diabetes mellitus in the Chinese hamster. Diabetologia. 6: 192.

14. Shirai, T., W. Welsh, and E. A. H. Sims. 1967. Diabetes mellitus in the Chinese hamster. II. The evolution of renal glomerulopathy. Diabetologia. 3: 266.

15. Federman, J. L., and G. C. Gerritsen. 1970. The retinal vasculariture of the Chinese hamster. a preliminary study. Diabetologia. 6 : 186.

16. Gerritsen, G. C., and W. E. Dulin. 1967. Characterization of diabetes in the Chinese hamster. Diabetologia. 3: 74.

17. Malaisse, W., F. Malaisse-Lagae, G. C. Gerritsen, W. E. Dulin, and P. H. Wright. 1967. Insulin secretion in vitro by the pancreas of the Chinese hamster. Diabetologia. 3 : 109.

18. Chang, A. Y. 1970. Insulin synthesis and secretion by isolated islets of spontaneously diabetic Chinese hamsters. In The Structure and Metabolism of the Pancreatic Islets. S. Falkmer, B. Hellman, and I.-B. Täljedal, editors. Pergamon Press, Inc., Elmsford, N. Y. 1st edition. 515.

19. Dulin, W. E., G. H. Lund, and G. C. Gerritsen. 1966. Studies on diabetes in the Chinese hamster: (1) pancreatic and plasma insulin, (2) glucose metabolism by diaphragm and fat. Diabetes. 15 : 523.

20. Sims, E. A. H., and B. R. Landau. 1967. Diabetes mellitus in the Chinese hamster. I. Metabolic and morphologic studies. Diabetologia. 3: 115.
21. Dulin, W. E., and G. C. Gerritsen. 1969. Summary of biochemical, physiological and morphological changes associated with diabetes in the Chinese hamster. Excerpta Med. Int. Congr. Ser. 172: 806.

22. Dulin, W. E., G. C. Gerritsen. 1972. Interaction of genetics and environment on diabetes in the Chinese hamster as compared with human and other diabetic animal species. Acta Diabetol. Lat. 9(Suppl. 1) : 48.

23. Grodsky, G. M., L. L. Bennett, D. F. Smith, and F. G. Schmid. 1967. Effect of pulse administration of glucose or glucagon on insulin secretion in vitro. Metab. (Clin. Exp.). 16: 222.

24. Grodsky, G. M., and R. Fanska. 1974. The in vitro perfused rat pancreas. Methods Enzymol. In press.

25. Curry, D. L., L. L. Bennett, and G. M. Grodsky. 1968. Dynamics of insulin secretion by the perfused rat pancreas. Endocrinology. 83: 572.

26. Grodsky, G. M., and P. H. Forsham. 1960. An immunochemical assay of total extractable insulin in man. $J$. Clin. Invest. 39 : 1070.

27. Unger, R. H., and A. M. Eisentraut. 1967. Glucagon. In Hormones in Blood. C. H. Gray and A. L. Bacharach, editors. Academic Press, Inc., New York. 2nd edition. 1: 83.

28. Gerich, J. E., M. A. Charles, S. R. Levin, P. H. Forsham, and G. M. Grodsky. 1972. In vitro inhibition of pancreatic glucagon secretion by diphenylhydantoin. J. Clin. Endocrinol. Metab. 35: 823.

29. Luyckx, A. S. 1972. Immunoassay for glucagon. In Glucagon, Molecular Physiology, Clinical and Therapeutic Implications. P. J. Lefebvre and R. H. Unger, editors. Pergamon Press, Inc., Elmsford, N. Y. 285.

30. Grodsky, G. M., and H. Tarver. 1956. Paper chromatography of insulin. Nature. (Lond.). 177: 223.

31. Grodsky, G. M. 1972. A threshold distribution hypothesis for packet storage of insulin and its mathematical modeling. J. Clin. Invest. 51 : 2047.

32. Grodsky, G. M. 1972. A threshold distribution hypothesis for packet storage of insulin. II. Effect of Calcium. Diabetes. 21 (Suppl. 2) : 584.

33. Müller, W. A., G. R. Faloona, and R. H. Unger. 1973. Hyperglucagonemia in diabetic ketoacidosis. Its prevalence and significance. Am. J. Med. 54: 52.

34. Cerasi, E., and R. E. Luft. 1969. The effect of an adenosine-3', $5^{\prime}$-monophosphate diesterase inhibitor (aminophylline) on the insulin response to glucose infusion in prediabetic and diabetic subjects. Horm. Metab. Res. $1: 162$.

35. Simpson, R. G., A. Benedetti, G. M. Grodsky, J. H. Karam, and P. H. Forsham. 1966. Stimulation of insulin release by glucagon in noninsulin-dependent diabetics. Metab. (Clin. Exp.). 15: 1046.

36. Cerasi, E., R. Luft, and S. Efendic. 1972. Decreased sensitivity of the pancreatic beta cells to glucose in prediabetic and diabetic subjects. A dose-response study. Diabetes. 21 : 224.

37. Robertson, R. P., D. Porte, Jr. 1973. The glucose receptor. A defective mechanism in diabetes mellitus distinct from the beta adrenergic receptor. J. Clin. Invest. $52: 870$.

38. Gerich, J. E., M. Langlois, V. S. Schneider, S. Dippe, G. M. Gustafson, J. H. Karam, and P. H. Forsham. 1973. Abnormalities of glucagon in diabetic syndromes: influence of obesity and response to oral glucose tolerance test (OGTT). Clin. Res. 21: 201. 
39. Müller, W. A., G. R. Faloona, and R. H. Unger. 1971. The effect of experimental insulin deficiency on glucagon secretion. J. Clin. Invest. 50: 1992.

40. Jarrousse, C., F. Rançon, G. Rosselin, and P. Freychet. 1973. Sécrétion de l'insulin et du glucagon par le pancréas du rat nouveau-né : effect du glucose et de l'adénosine 3'-5' cyclic monophosphate. C. R. Helsd. Seances. Acad. Sc. Ser. D Sci. Nat. (Paris). 276: 797.

41. Gerich, J. E., M. Langlois, V. Schneider, C. Noacco, and P. H. Forsham. 1973. Effect of cyclic-AMP
(CAMP) on glucagon secretion in man. Diabetes. 22 (Suppl. 1) : 301

42. Unger, R. H. 1971. Glucagon physiology and pathophysiology. N. Engl. J. Med. 285: 443.

43. Falconer, D. S. 1966. Genetic aspects of breeding methods. In The UFAW Handbook on the Care and Management of Laboratory Animals. W. Lane-Petter, A. N. Worden, B. F. Hill, J. S. Paterson, and H. G. Vevers, editors. The Williams and Wilkins Co., Baltimore. 3rd edition. 72 . 